\section{Kidney \\ Blood Pressure Research}

\title{
Enhanced Renal Afferent Arteriolar Reactive Oxygen Species and Contractility to Endothelin-1 Are Associated with Canonical Wnt Signaling in Diabetic Mice
}

\author{
Suping Zhang ${ }^{\mathrm{a}}$ Qian Huang ${ }^{\mathrm{a}, \mathrm{b}}$ Qiaoling Wang ${ }^{\mathrm{a}}$ Qin Wang ${ }^{\mathrm{a}}$ Xiaoyun Cao \\ Liang Zhao a,c Nan Xu ${ }^{a}$ Zhengbing Zhuge ${ }^{a}$ Jianhua Mao ${ }^{a}$ Xiaodong Fu ${ }^{c}$ \\ Ruisheng Liu ${ }^{d}$ Christopher S. Wilcox ${ }^{e}$ Andreas Patzak ${ }^{f}$ Lingli Lie $^{\text {En Yin Laia,e }}$ \\ aDepartment of Physiology, and the Children's Hospital, Zhejiang University School of Medicine, \\ Hangzhou, 'Department of Physiology, Quanzhou Medical College, Quanzhou, 'Department of \\ Physiology, School of Basic Medical Sciences, Guangzhou Medical University, Guangzhou, China, \\ dDepartment of Molecular Pharmacology \& Physiology, University of South Florida College of \\ Medicine, Tampa, Florida, eDivision of Nephrology and Hypertension, and Hypertension Center, \\ Georgetown University, Washington, DC, USA, 'Institute of Vegetative Physiology, Charité- \\ Universitätsmedizin Berlin, Berlin, Germany
}

\section{Key Words}

Endothelin-1 - Reactive oxygen species - Canonical Wnt signaling - Afferent arteriole • Diabetes mellitus

\begin{abstract}
Background/Aims: Canonical Wnt signaling is involved in oxidative stress, vasculopathy and diabetes mellitus but its role in diabetic renal microvascular dysfunction is unclear. We tested the hypothesis that enhanced canonical Wnt signaling in renal afferent arterioles from diabetic mice increases reactive oxygen species (ROS) and contractions to endothelin-1 (ET-1). Methods: Streptozotocin-induced diabetes or control C57BI/6 mice received vehicle or sulindac (40 mg $\left.\mathrm{kg}^{-1} \cdot \mathrm{day}^{-1}\right)$ to block Wnt signaling for 4 weeks. ET-1 contractions were measured by changes of afferent arteriolar diameter. Arteriolar $\mathrm{H}_{2} \mathrm{O}_{2}, \mathrm{O}_{2}-$, protein expression and enzymatic activity were assessed using sensitive fluorescence probes, immunoblotting and colorimetric assay separately. Results: Compared to control, diabetic mouse afferent arteriole had increased $\mathrm{O}_{2}^{-}(+84 \%)$ and $\mathrm{H}_{2} \mathrm{O}_{2}(+91 \%)$ and enhanced responses to ET-1 at $10^{-8}$ mol. $\left.\right|^{-1}(-72 \pm 4 \%$ of versus $-43 \pm 4 \%, P<0.05)$ accompanied by reduced protein expressions and activities for catalase and superoxide dismutase 2 (SOD2). Arteriolar $\mathrm{O}_{2}-$ was increased further by ET-1 and contractions to ET-1 reduced by PEG-SOD in both groups whereas $\mathrm{H}_{2} \mathrm{O}_{2}$ unchanged

S. Zhang and Q. Huang contributed equally to this study.

\begin{tabular}{cl}
\hline En Yin Lai, MD, PhD & Department of Physiology, Zhejiang University School of Medicine, \\
& Yuhangtang Road 866, Hangzhou 310058 (China) \\
& E-Mail laienyin@zju.edu.cn
\end{tabular}
\end{abstract}




\section{Kidney \\ Blood Pressure Research}

by ET-1 and contractions were reduced by PEG-catalase selectively in diabetic mice. The Wnt signaling protein $\beta$-catenin was upregulated (3.3-fold decrease in $p$ - $\beta$-catenin/ $\beta$-catenin) while

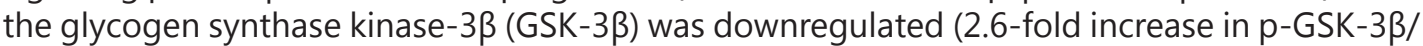
GSK-3 $\beta$ ) in preglomerular vessels of diabetic mice. Sulindac normalized the Wnt signaling proteins, arteriolar $\mathrm{O}_{2}-\mathrm{H}_{2} \mathrm{O}_{2}$ and ET-1 contractions while doubling microvascular catalase and SOD2 expression in diabetic mice. Conclusion: Increased ROS, notably $\mathrm{H}_{2} \mathrm{O}_{2}$ contributes to enhanced afferent arteriolar responses to ET-1 in diabetes, which is closely associated with Wnt signaling. Antioxidant pharmacological strategies targeting Wnt signaling may improve vascular function in diabetic nephropathy.

\section{Introduction}

Diabetes mellitus (DM) is a microvascular disorder characterized with a progressive decrease in renal blood flow (RBF) although the RBF and glomerular filtration rate (GFR) may increase early in its hyperfiltration phase [1]. The tone of renal afferent arteriole is the key element in regulation of RBF. The arteriolar tone is determined by many factors, two of which are the major contributors to increase the arteriolar tone: apparent oxidative stress in animal renal afferent arterioles[1], and elevated plasma and tissue endothelin 1 (ET-1) levels in animal models and patients with DM [2-4].

Oxidative stress is a shift of balance oxidants versus antioxidants (superoxide dismutase (SOD) and catalase) in favor of oxidants, thereby resulting in excessive reactive oxygen species (ROS), mainly superoxide anion $\left(\mathrm{O}_{2} \cdot\right)$ and hydrogen peroxide $\left(\mathrm{H}_{2} \mathrm{O}_{2}\right)$, in the tissues. Both $\mathrm{O}_{2}{ }^{-}$and $\mathrm{H}_{2} \mathrm{O}_{2}$ have been implicated in modulating myogenic contraction. $\mathrm{O}_{2}$ - promotes normal myogenic contractions [5, 6] whereas $\mathrm{H}_{2} \mathrm{O}_{2}$ has opposite effects [6, 7]. Diabetic animals have increased ROS in renal afferent arterioles [1] and increased responses to ET-1 in microvessels from pancreatic islet [8] and the optic fundus capillary [9]. Studies in penile arteries from insulin-resistant obese rats has demonstrated that $\mathrm{O}_{2} \cdot$ - enhances contractions to ET-1[10], but the contribution of $\mathrm{H}_{2} \mathrm{O}_{2}$ is unclear.

The canonical Wnt pathway entails signaling through inactivation of glycogen synthase

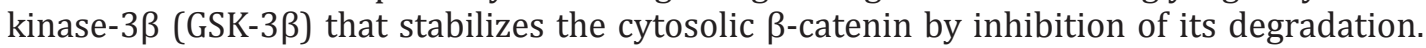
This pathway underlines renal damage from high glucose $[11,12]$. Canonical WNT signaling can regulate redox signaling in vasculatures, [13] mitochondrial system [14] and diabetic animal [15]. However, its specific role in regulation of renal microvascular reactivity in DM has not been determined. Therefore, the aim of this study was to investigate whether enhanced canonical Wnt signaling contributes to the increased ROS and thereby to enhanced contractions to ET- 1 in renal afferent arterioles of diabetic mice. $\mathrm{O}_{2}-$ and $\mathrm{H}_{2} \mathrm{O}_{2}$ in the arterioles were assessed by fluorescence and biochemical determination and from changes in vascular function after incubation with PEG-SOD or PEG-catalase. The specific role of canonical Wht signaling in regulation of ROS was assessed from the responses to 4 weeks of oral administration of its inhibitor sulindac in streptozotocin (STZ)-induced diabetic mice [16].

\section{Materials and Methods}

\section{Animals}

Male adult C57Bl/6 mice (SLAC laboratory animal company, Shanghai, China) with an average weight of $25 \mathrm{~g}$ were located under standard conditions with free access to standard pellet chow and tap water. All the experiments were performed with approval from the Institute Animal Care and Ethical Committee of Zhejiang University School of Medicine. 


\section{Kidney Blood Pressure Research}

\section{Induction of STZ-induced diabetic mice model}

Diabetes was induced by intraperitoneally injections of Streptozotocin (STZ, diluted in citrate buffer, $0.1 \mathrm{M}, \mathrm{pH} 4.5$ ) at $70 \mathrm{mg} \cdot \mathrm{kg}^{-1} \cdot \mathrm{day}^{-1}$ for 4 consecutive days. Seven days after STZ injection, mice with glucose levels over $16.7 \mathrm{mmol} \cdot \mathrm{l}^{-1}$ were selected for the following experiments. Citrate buffer instead of STZ was set as vehicle control. The food and water intake, body weight and kidney weight were measured in all experimental groups. Plasma glucose level was monitored by a contour glucose meter (Roche, Mannheim, Germany) once a week for 4 weeks. To investigate the effect of Wnt signaling on ROS generation and arteriolar activity, sulindac $\left(40 \mathrm{mg} \cdot \mathrm{kg}^{-1} \cdot \mathrm{day}^{-1}\right)$ or vehicle was administered intragastrically to vehicle control and diabetic mice daily for 4 weeks.

\section{Isolation and perfusion of renal afferent arterioles}

Afferent arterioles were isolated and perfused as previously described $[17,18]$. Briefly, an afferent arteriole attached to its intact glomerulus was separated from the renal cortex at $4{ }^{\circ} \mathrm{C}$ in Dulbecco's modified Eagle's medium (DMEM) and transferred to a temperature-regulated chamber on the stage of an inverted microscope (IX71, Olympus, Japan). The afferent arteriole was perfused at $37^{\circ} \mathrm{C}$ with an array of glass pipettes. The pressure in the tip of perfusion pipette was $60 \mathrm{mmHg}$. Only one afferent arteriole per animal was used for one experiment. Arterioles with a fast and complete contraction in response to $\mathrm{KCl}$ (100 $\mathrm{mmol} \cdot \mathrm{l}^{-1}$ ) solution were used in the experiments.

\section{Measurement of afferent arteriolar diameter}

The experimental data were recorded real-time and luminal diameters were measured to determine the effect of vasoactive substances. In all series, the last 30 seconds of the 2 minutes control or treatment period was used for statistical analysis of steady state responses [19]. The protocols were performed (one arteriole for one protocol) as follows: (1) cumulative bath addition of ET-1 $\left(10^{-12}-10^{-8} \mathrm{~mol} \cdot \mathrm{l}^{-1}\right)$; (2) preincubation with PEG-catalase (1000 units $\mathrm{ml}^{-1}, 30 \mathrm{~min}$ ) [6] followed by cumulative bath addition of ET-1; (iii) preincubation with PEG-SOD (200 units $\cdot \mathrm{ml}^{-1}, 30 \mathrm{~min}$ ) [19] followed by cumulative bath addition of ET-1; (iv) incubation of $\mathrm{H}_{2} \mathrm{O}_{2}\left(10 \mu \mathrm{mol} \cdot \mathrm{l}^{-1}, 15 \mathrm{mins}\right)$. Contractions of afferent arterioles are presented as relative values of luminal diameters (percentage of the initial diameter).

\section{Isolation of renal preglomerular arterioles}

Isolation of preglomerular arterioles was performed as previously described [19-21]. Briefly, the renal vessels in the anesthetized mice were perfused with $1 \%$ iron oxide in physiological phosphate buffered saline (PBS). The perfused segments of renal preglomerular microvessels (interlobular arteries and afferent arterioles) were isolated by using the high-performance magnet. The isolated microvessels were used for the following biochemical analysis.

\section{Measurement of superoxide and hydrogen peroxide}

As described previously,[19] in the perfused individual afferent arteriole, changes in ethidium:dihydroethidium (E:DHE) fluorescence ratio and 6-carboxy-2', 7'-dichlorodihydrofluorescein diacetate (C- $\mathrm{H}_{2}$ DCFDA) were used for detection of $\mathrm{O}_{2}{ }^{-}$and $\mathrm{H}_{2} \mathrm{O}_{2}$, respectively. In the isolated preglomerular arterioles, $\mathrm{O}_{2}$ and $\mathrm{H}_{2} \mathrm{O}_{2}$ were analyzed using standard assay kits according to manufactures instructions. $\mathrm{O}_{2}$ - or $\mathrm{H}_{2} \mathrm{O}_{2}$ levels were presented as units or $\mu \mathrm{mol}$ per milligram protein.

\section{Enzymatic activity assay}

Endogenous antioxidant enzymes, SOD and catalase, were measured using colorimetric assay kits according to the manufacturers' instructions, as described previously [19]. Briefly, the isolated preglomerular arterioles were homogenized at $4{ }^{\circ} \mathrm{C}$. Enzymatic activities in the supernatants were determined based on its ability to form $\mathrm{H}_{2} \mathrm{O}_{2}$ and degradation rate of $\mathrm{H}_{2} \mathrm{O}_{2}$ for SOD and catalase, respectively.

\section{Western Blot analysis}

Each protein sample was extracted from the isolated preglomerular arterioles of one mouse. The samples were loaded and separated by SDS-polyacrylamide gel electrophoresis and transferred onto polyvinylidene difluoride membranes. The specific proteins on the membranes were probed with specific 


\section{Kidney Blood Pressure Research}

Kidney Blood Press Res 2018;43:860-871

\begin{tabular}{l|l}
\hline DOI: $10.1159 / 000490334$ & (C) 2018 The Author(s). Published by S. Karger AG, Basel
\end{tabular}

Published online: 5 June, 2018 www.karger.com/kbr

primary antibodies $[22,23]$ for GSK-3 $\beta$, phospho-GSK-3 $\beta$ (Ser9), $\beta$-catenin, phospho- $\beta$-catenin (Ser33/37/ The41), SOD1, SOD2, catalase or $\beta$-actin and second horseradish peroxidase-labeled IgG anti-rabbit (or mouse) antibody. The probed bands were visualized by enhanced chemiluminescent substrates (ECL, Thermo Scientific) and analyzed by using Image J software (National Institutes of Health, Bethesda, MD).

\section{Chemicals and reagents}

Reagent sources were as follows: DMEM, sulindac, ET-1, PEG-catalase, PEG-SOD, apocynin (SigmaAldrich, St Louis, MO); DHE, C-H ${ }_{2}$ DCFDA (Invitrogen Life Technologies, Eugene, Dregon, USA); BCA protein assay kit, $\mathrm{H}_{2} \mathrm{O}_{2}$ assay kit, catalase assay kit and total SOD assay kits (Beyotime, Shanghai, China). $\mathrm{O}_{2} \cdot$ assay kit (Jiancheng Bioengineering Institute, Najing, China). Antibody sources were as follows: rabbit anti-GSK$3 \beta$, rabbit anti-phospho-GSK-3 $\beta$ (Ser9), rabbit anti- $\beta$-catenin, rabbit anti-phospho- $\beta$-catenin (Ser33/37/ Thr41), rabbit anti-SOD1 (\#2770), rabbit anti-SOD2 (\#13194), rabbit anti-catalase (\#14097), horseradish peroxidase-labeled IgG anti-rabbit (or mouse) antibodies (Cell Signaling Technology, Beverly, CA, USA) and mouse anti- $\beta$-actin (Abcam, Cambridge, MA, USA).

\section{Statistical analysis}

Data were presented as means \pm SEM values. Statistical comparisons were made by ANOVA with a Bonferroni post hoc test for multiple comparisons test. An analysis of variance with repeated measurements (ANOVA) was used to test concentration-dependent changes in afferent arteriolar diameter and to assess the differences in the afferent arteriolar responses, t-Test and One-Way ANOVA followed by Student-NewmanKeuls post hoc test were used for other comparisons among groups. All statistical calculations were made using Graphpad Prism (6.01, La Jolla, CA, USA). $P$-value $<0.05$ was accepted as statistically significant.

\section{Results}

There were no differences in food and water intake, body weight and kidney weight among all groups. However, blood glucose was dramatically higher in diabetic mice $20.7 \pm$ 1.0 versus $6.7 \pm 0.3 \mathrm{mmol}^{-1} \mathrm{l}^{-1}, P<0.001$ ). Administration of sulindac did not affect the blood glucose levels in either non-diabetic or diabetic mice (Table 1).

Enhanced ET-1 responses of afferent arterioles are associated with excessive ROS in diabetic mice

Afferent arterioles from diabetic mice had increased responses to ET- 1 at $10^{-8} \mathrm{~mol} \cdot \mathrm{l}^{-1}$ (DM: $-72 \pm 4 \%$ versus control: $-43 \pm 4 \%, P<0.05$ ) (Fig. 1). Compared to controls, the ethidium:dihydroethidium (E:DHE) fluorescence ratio (probe for $\mathrm{O}_{2}^{-}$) and the 6-carboxy$2^{\prime}, 7^{\prime}$-dichlorodihydrofluorescein diacetate $\left(\mathrm{H}_{2}\right.$ DCFDA) fluorescence (probe for $\mathrm{H}_{2} \mathrm{O}_{2}$ ) were increased in the perfused afferent arterioles from diabetic mice (Fig. $2 \mathrm{~A}$ and $\mathrm{B}$ ). E:DHE ratio increased (Fig. 2A) whereas $\mathrm{H}_{2}$ DCFDA fluorescence levels similar to their basal levels (Fig. 2B) after incubation with ET-1 both in normal and diabetic arterioles. $\mathrm{O}_{2}-$ and $\mathrm{H}_{2} \mathrm{O}_{2}$ concentrations in the isolated preglomerular arterioles were increased in diabetic animals (Fig. 2C and D). Both measurements, fluorescence and biochemical determination, suggest increased $\mathrm{O}_{2}^{-}$and $\mathrm{H}_{2} \mathrm{O}_{2}$ concentrations in arterioles of diabetic mice compared to controls. Bath addition of PEG-SOD (200 units $\cdot \mathrm{ml}^{-1}$, $30 \mathrm{~min}$ ) reduced the responses to ET-1 in both control and diabetic mouse arterioles (Fig. 1A). On the other hand, bath addition of PEG-catalase (1000 units. $\mathrm{ml}^{-1}, 30 \mathrm{~min}$ ) substantially reduced the responses to ET-1 selectively in arterioles from diabetic mice (Fig. 1B). In consistent to the vasodilatory responses to $\mathrm{H}_{2} \mathrm{O}_{2}$ in normal afferent arterioles [19], incubation of afferent

Table 1. Blood glucose levels (mmol. $\mathrm{l}^{-1}$ ) in nondiabetic and diabetic mice. Diabetic vs Non-diabetic: $\mathrm{P}<0.001$; Non-diabetic + Sulindac vs Non-diabetic: NS; Diabetic + Sulindac vs Diabetic: NS

\begin{tabular}{lccc} 
Mice & Mean \pm SEM & N & T-test \\
\hline Non-diabetic & $6.7 \pm 0.3$ & 8 & \\
Diabetic & $20.7 \pm 1.0$ & 17 & $\mathrm{P}<0.001$ \\
Non-diabetic + Sulindac & $6.9 \pm 0.3$ & 8 & NS \\
Diabetic + Sulindac & $21.4 \pm 0.9$ & 16 & NS \\
\hline
\end{tabular}




\section{Kidney Bloód Pressure Research}

arterioles with $\mathrm{H}_{2} \mathrm{O}_{2}\left(10 \mu \mathrm{mol} \cdot \mathrm{l}^{-1}, 15 \mathrm{~min}\right)$ led to a similar vasodilation in vehicle controls (by ANOVA, $P=N S$ ). However, a slowly developing vasocontraction to $\mathrm{H}_{2} \mathrm{O}_{2}$ was observed in diabetic mice (by ANOVA, $P<0.001$, Fig. 3 ).

\section{Canonical Wht signaling is enhanced in diabetic mice}

Canonical Wht signaling was activated in renal microvessels from diabetic mice, as evidenced by a 2.6 -fold increase in protein expression for p-GSK-3 $\beta /$ GSK3 $\beta$ ratio (Fig. 4A) and a 3.3 -fold decrease in $p$ - $\beta$-catenin/ $\beta$-catenin ratio (Fig. 4B). These changes were restored to normal in the preglomerular arterioles from diabetic mice treated with sulindac to inhibit Wnt signaling (Fig. 4).

Expressions and activities of catalase and SOD2 are decreased in renal microvessels from diabetic mice

The expression of catalase and SOD2 were decreased in renal microvessels from diabetic mice, but these effects were prevented by sulindac (Fig. 5). There were parallel reductions in catalase and total SOD activities in diabetic mice and were improved by treatment with sulindac (Fig. 6).

Sulindac normalizes the ET-1 responses of afferent arterioles through reduction of ROS in diabetic mice

Given sulindac to mice for 4 weeks, simultaneously lowered the E:DHE ratio and $\mathrm{H}_{2}$ DCFDA fluorescence (Fig. 2A and B) as well as $\mathrm{O}_{2}^{-}$and $\mathrm{H}_{2} \mathrm{O}_{2}$ concentrations (Fig. 2C and D) and normalized the ET-1 responses of afferent arterioles in diabetic mice. However, it did not affect the ET-1 responses (Fig. 1C) or ROS generation (data not shown) of afferent arterioles in non-diabetic mice. Therefore, in the following Figures $(2,4,5,6)$, we did not show its effects in non-diabetic setting.

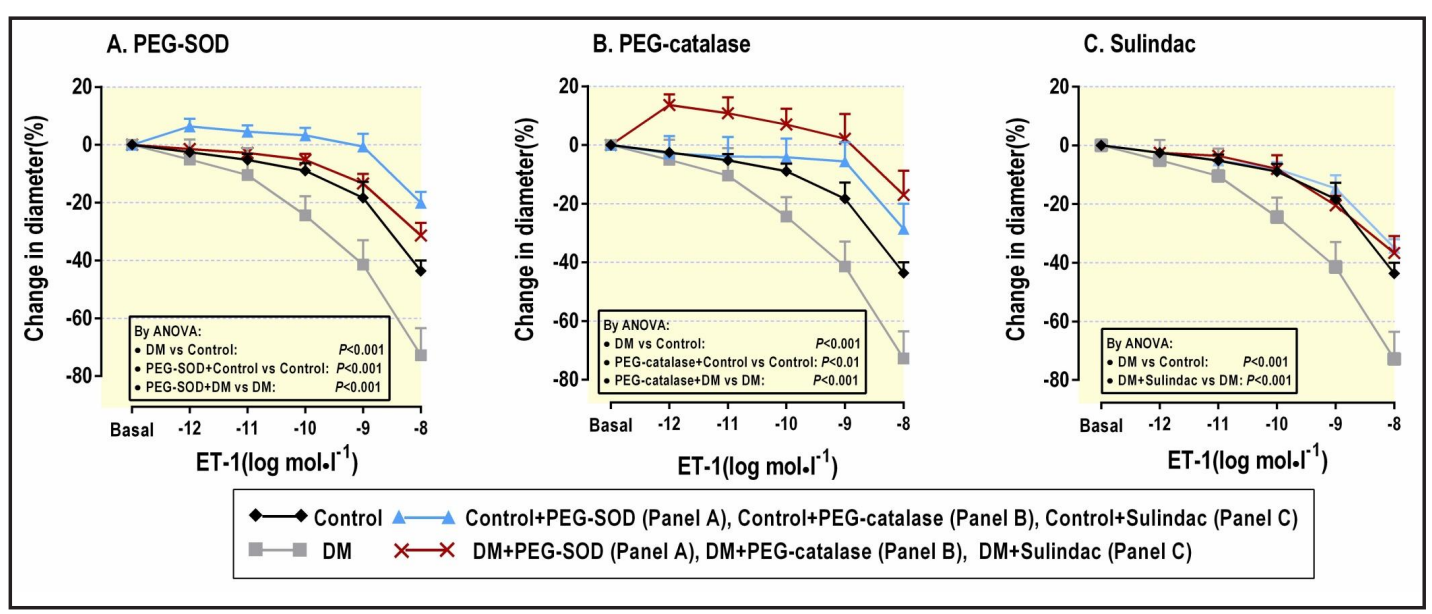

Fig. 1. Mean \pm SEM values $(n=5-6)$ for ET-1 responses of afferent arterioles from control mice in the absence (black diamonds with black line) or presence of PEG-SOD (200 units $\mathrm{mL}^{-1}$ ) (A) or PEG-catalase (1000 units $\mathrm{mL}^{-1}$ ) (B) or Sulindac (40 mg. $\mathrm{kg}^{-1}$. day-1 for 4 weeks) (C) (blue triangles with blue line), diabetic mice in the absence (grey squares with grey line) or presence of PEG-SOD (A) or PEG catalase (B) or Sulindac) (C) (red crosses with red line). Data are shown for changes in luminal dimeters of afferent arterioles in response to ET-1 $\left(10^{-12}-10^{-8} \mathrm{~mol} \cdot \mathrm{l}^{-1}\right)$. ANOVA, analysis of variance; ET-1, endotheline-1; PEG, polyethylene glycol; SOD, superoxide dismutase; DM, diabetes mellitus. 


\section{Kidney Blood Pressure Research}

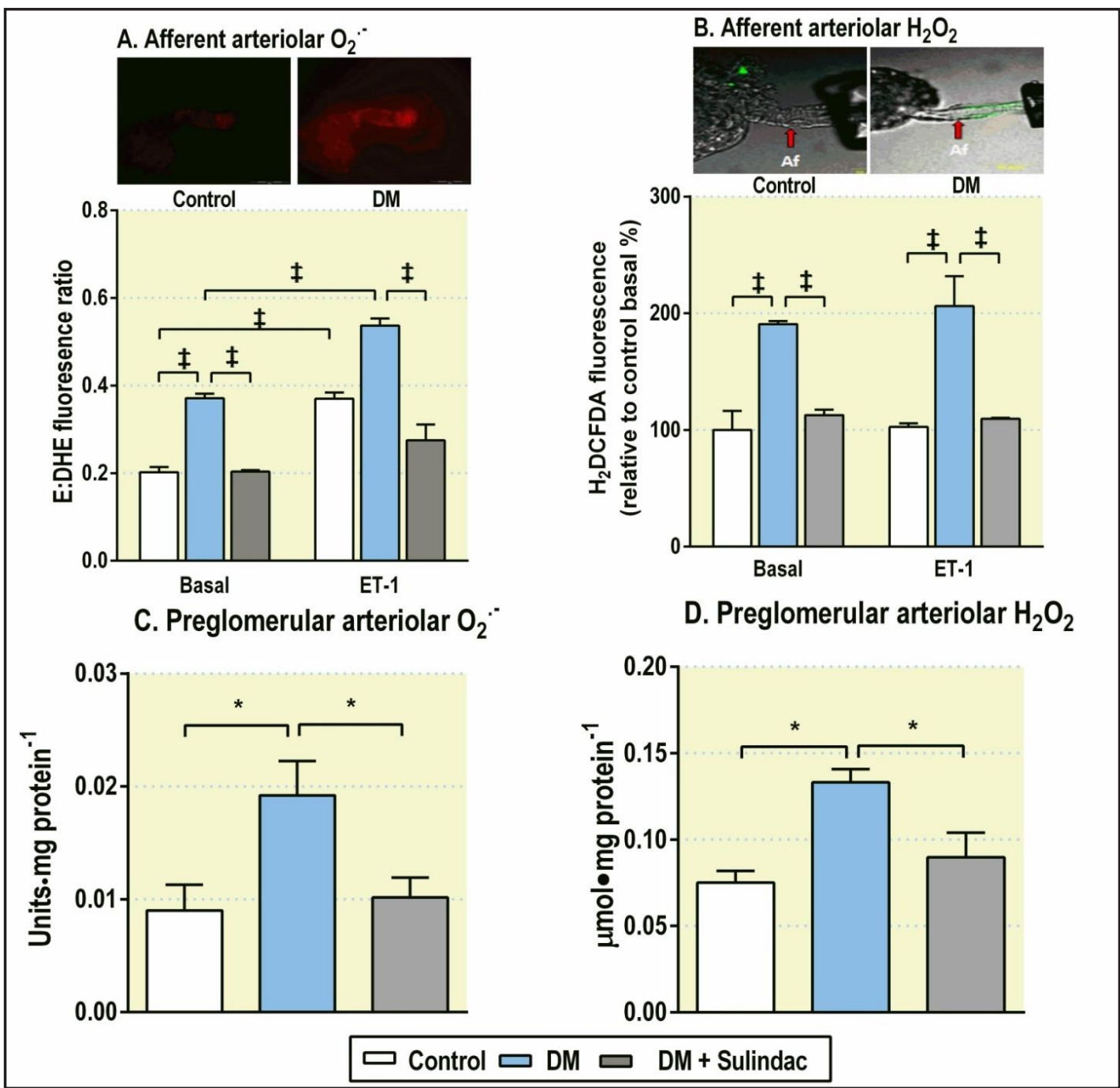

Fig. 2. Mean \pm SEM values $(n=5)$ for $\mathrm{O}_{2}^{--}$and $\mathrm{H}_{2} \mathrm{O}_{2}$ in the perfused individual afferent arteriole $(A$ and $B)$ or in the isolated preglomerular arterioles ( $\mathrm{C}$ and $\mathrm{D}$ ) from control mice (open boxes), diabetic mice (blue filled boxes) and sulindac treated diabetic mice (grey filled boxes). Data are shown as the basal levels of ethidium:dihydroethidium (E:DHE) fluorescence ratio for $\mathrm{O}_{2}-\mathrm{H}_{2}$ DCFDA fluorescence for $\mathrm{H}_{2} \mathrm{O}_{2}$, their changes in response to ET-1 $\left(10^{-8} \mathrm{~mol} \cdot \mathrm{l}^{-1}\right)$ in the perfused individual arteriole and units (or $\left.\mu \mathrm{mol}\right) \cdot \mathrm{mg}-1$ protein for their concentrations in the isolated preglomerular arterioles. Comparing groups: ${ }^{*} \mathrm{P}<0.05 ; \neq \mathrm{P}<0.001$.

Fig. 3. Time course of changes in luminal diameter of perfused afferent arterioles $(n=5)$ from normal control (without injection, black diamonds with solid line), vehicle control (7 days after injection of citrate buffer, grey diamonds with grey line) and diabetic mice (7 days after injection of STZ, blue triangles with blue line) by bath addition of $\mathrm{H}_{2} \mathrm{O}_{2}\left(10 \mu \mathrm{mol} \cdot \mathrm{l}^{-1}\right)$. ANOVA, analysis of variance.

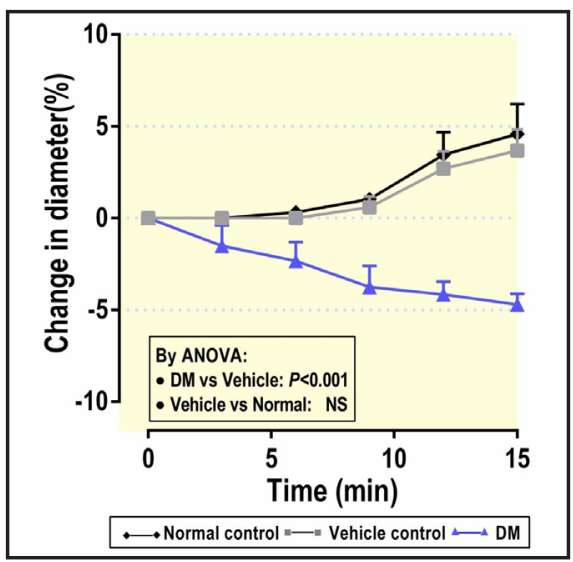




\section{Kidney Blood Pressure Research}

Fig. 4. Mean \pm SEM values $(\mathrm{n}=5)$ for the ratio of phosphorylated protein p-GSk-3 $\beta / G S k-3 \beta$ (A) and $\mathrm{p}-\beta$-catenin $/ \beta$-catenin (B) in preglomerular arterioles from control mice (open boxes), diabetic mice (blue filled boxes) and Sulindac treated diabetic mice (grey filled boxes). Comparing groups: * $\mathrm{P}<0.05 ; \neq \mathrm{P}<$ 0.001 .
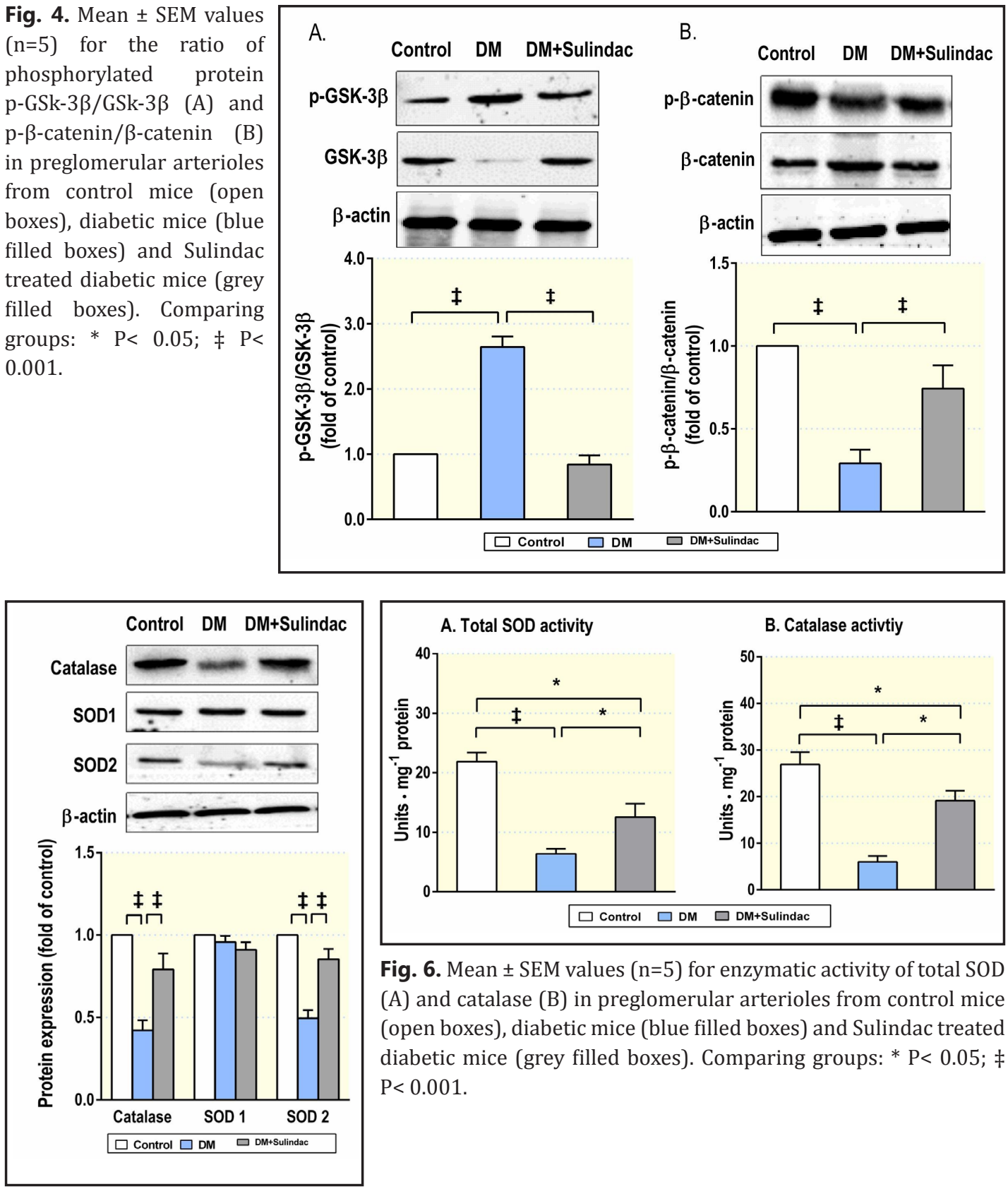

Fig. 6. Mean \pm SEM values $(n=5)$ for enzymatic activity of total SOD (A) and catalase (B) in preglomerular arterioles from control mice (open boxes), diabetic mice (blue filled boxes) and Sulindac treated diabetic mice (grey filled boxes). Comparing groups: $* \mathrm{P}<0.05$; $\mathrm{P}<0.001$.

Fig. 5. Mean \pm SEM values $(n=5)$ for protein expression of catalase, SOD1 and SOD2 in preglomerular arterioles from control mice (open boxes), diabetic mice (blue filled boxes) and Sulindac treated diabetic mice (grey filled boxes). Comparing groups: $\ddagger \mathrm{P}<0.001$. 


\section{Kidney Blood Pressure Research}

Kidney Blood Press Res 2018;43:860-871

\begin{tabular}{l|l}
\hline DOI: 10.1159/000490334 & (C) 2018 The Author(s). Published by S. Karger AG, Base
\end{tabular}

Published online: 5 June, 2018

www.karger.com $/ \mathrm{kbr}$

\section{Discussion}

The main finding of the present study is that diabetes enhances the responses to ET-1 and the increases of $\mathrm{O}_{2}-$ and $\mathrm{H}_{2} \mathrm{O}_{2}$ substantially in renal afferent arterioles. The arteriolar $\mathrm{O}_{2}$ was increased in control and increased further in diabetic mice by incubation with maximal concentrations of ET-1. These changes of $\mathrm{O}_{2}-$ and $\mathrm{H}_{2} \mathrm{O}_{2}$ in diabetic mice were all prevented in those treated with sulindac that was confirmed to inhibit Wnt signaling from the reversal of expression of Wnt signaling proteins. The increased $\mathrm{O}_{2}{ }^{-}$in diabetic mouse arterioles, and its prevention by sulindac, was accompanied by decreased protein expression for SOD2 and decreased total SOD activities whereas the corresponding changes in $\mathrm{H}_{2} \mathrm{O}_{2}$ were accompanied by similar changes in catalase. Incubation of arterioles from control or diabetic mice with PEG-SOD attenuated their responses to ET-1 whereas incubation with PEG-catalase markedly attenuated the responsiveness to ET- 1 selectively in diabetic mice. The enhanced ET-1 response of individual afferent arteriole from diabetic mice extends previous reports in microvessels $[8,24]$ or renal arteries [25].

Oxidative stress contributes to diabetic vasculopathy in animal models and in particular with diabetic nephropathy [26]. We confirmed increases of $\mathrm{O}_{2}$ and $\mathrm{H}_{2} \mathrm{O}_{2}$ in renal arterioles from diabetic mice. $\mathrm{O}_{2}$ - is formed enzymatically or in mitochondria by the univalent reduction of oxygen, its major route of metabolism is to $\mathrm{H}_{2} \mathrm{O}_{2}$ via SOD [27]. The $\mathrm{H}_{2} \mathrm{O}_{2}$ level is regulated by various peroxidase of which catalase is most important in small vessels, for its abundance and higher affinity to $\mathrm{H}_{2} \mathrm{O}_{2}$. Thus, we evaluated arteriolar protein levels and activities of SODs and catalase separately to assess the extent of oxidative stress, for their important roles in regulation of cellular ROS. We reported previously that deficiency in SOD1, SOD2 or SOD3 had dramatically increased afferent arteriolar level of $\mathrm{O}_{2} \cdot$ and enhanced contractility [28]. Transfer of SOD1 or SOD2 gene to the diabetic vessels decreased $\mathrm{O}_{2} \cdot$ and improved vascular function $[29,30]$. We confirmed the reduced expression of SOD2 in arterioles from diabetic mice, but expression of SOD1 was maintained. The reduction in SOD2 may underline the finding that mitochondria are the main site of producing superoxide in diabetes $[31,32]$. Since SOD2 plays a central role in metabolizing $\mathrm{O}_{2}$ - in mitochondria the maintained level of SOD1 may prevent $\mathrm{O}_{2} \cdot-$ overproduction in diabetic conditions. Interestingly, SOD activity in vascular beds showed an increase [33] or decrease [34, 35] in different animal models of diabetes. Likewise, vascular catalase activity or protein level also have been reported to be increased or decreased in diabetes $[34,36,37]$. These inconsistent results perhaps depend on the stage or severity of the diabetic model. Our study clearly demonstrates a comprised antioxidant SOD and catalase system in the vasculature of diabetic mice that could contribute to the increases in $\mathrm{O}_{2}^{-}$and $\mathrm{H}_{2} \mathrm{O}_{2}$. However, our key findings need further confirmation in other non-toxic diabetes model.

Previously studies have reported that ET-1 modulates renal arteriolar tone via generation of $\mathrm{O}_{2}^{-}$[38]. Our study confirmed that metabolism of $\mathrm{O}_{2}^{-}$with PEG-SOD reduced ET-1 responses in both control and diabetic mice. Afferent arteriolar levels of $\mathrm{O}_{2}^{-}$were increased significantly by ET-1 at $10^{-7} \mathrm{~mol} \cdot \mathrm{l}^{-1}$ in arterioles from both normal and diabetic mice. Thus, generation of $\mathrm{O}_{2}$ contributes to ET- 1 induced arteriolar contractions in both normal and diabetic mouse arterioles. Compared to $\mathrm{O}_{2}-\mathrm{H}_{2} \mathrm{O}_{2}$ has been reported variously to exert vasoconstriction or vasodilation depending on experimental conditions [5, 39]. We confirmed our previous report that $10^{-5} \mathrm{~mol} \cdot \mathrm{l}^{-1}$ of $\mathrm{H}_{2} \mathrm{O}_{2}$ vasodilates normal afferent arterioles [19]. In contrast, we now report that $\mathrm{H}_{2} \mathrm{O}_{2}$ exerts a steady and sustained contraction of afferent arterioles from diabetic mice. The mechanisms of these different effects are unclear. The possible mediators are increased contractile protein expression [40] or decreased potassium channels protein $[6,41]$. We confirmed that metabolism of $\mathrm{H}_{2} \mathrm{O}_{2}$ with PEG-catalase did not affect contractions of arterioles from normal mice [7]. However, PEG-catalase markedly reduced the responsiveness to ET-1 in arterioles from diabetic mice. Increased $\mathrm{H}_{2} \mathrm{O}_{2}$ was related to diabetes rather than ET- 1 since it was found in diabetic arterioles under basal condition and was not increased even by $10^{-7} \mathrm{~mol} \cdot \mathrm{l}^{-1}$ of ET- 1 . This is the first report 


\section{Kidney \\ Blood Pressure Research}

\begin{tabular}{l|l}
\hline Kidney Blood Press Res 2018;43:860-871 \\
\hline DOI: 10.1159/000490334 & $\begin{array}{l}\text { (c) 2018 The Author(s). Published by S. Karger AG, Basel } \\
\text { www.karger.com/kbr }\end{array}$ \\
\hline Published online: 5 June, 2018 &
\end{tabular}

Zhang et al.: ET-1 and Canonical Wnt Signaling in Afferent Arteriole

that increased ROS generated by diabetes, especially $\mathrm{H}_{2} \mathrm{O}_{2}$, are responsible for the increased responses to ET-1.

Canonical Wnt signaling inactivates GSK-3 $\beta$, thereby stabilizing the arterial transcription factor $\beta$-catenin that activates many target genes,[42] notably that implicated in the metabolic syndrome and diabetes $[43,44]$. We detected activation of the canonical Wnt pathway with increased $\beta$-catenin and decreased GSK-3 $\beta$ in preglomerular arterioles from diabetic mice that were corrected by sulindac. This effect was in confirmed with previous reports that even though sulindac is a commonly used non-steroidal anti-inflammatory drug, it also significantly suppressed Wnt/ $\beta$-catenin signaling [45]. Oxidative stress has been reported variously to activate [46] or inhibit [47] canonical Wnt signaling. However, our data confirmed other reports that Wnt/ $\beta$-catenin pathway promotes ROS generation [48-50]. We found that administration of sulindacin diabetic mice decreased $\mathrm{H}_{2} \mathrm{O}_{2}$ and $\mathrm{O}_{2} \cdot$ and increased catalase and SOD2 expression and activities in preglomerular arterioles. We noticed that the activities of arteriolar total SOD and catalase recovered partially with more pronounced reduction of ROS levels after administration of sulindac to diabetic mice. Moreover, sulindac also blunted $\mathrm{O}_{2}-$ and $\mathrm{H}_{2} \mathrm{O}_{2}$ generation induced by ET- 1 in diabetic mice. This indicates the important roles for sulindac in reducing microvascular ROS in diabetes. Overexpression of $\beta$-catenin in the endothelium also increased ROS and led to vascular dysfunction [13]. Our data indicate that activation of canonical Wnt signaling is essential for excessive vascular ROS in diabetes mellitus and point to reduction in the ROS metabolism pathways as major targets. In this study, we acknowledge some limitations. First, the plasma creatinine was not measured in this study, thus it is unclear whether the drug had such an effect in STZ-induced diabetic mice. Second, sulindac used in this study is not a perfect inhibitor for canonical Wnt signaling.

\section{Conclusion}

Present study provides an evidence that diabetes leads to activation of canonical Wnt signaling that enhances renal afferent arteriolar response to ET-1 through promoting ROS, notably $\mathrm{H}_{2} \mathrm{O}_{2}$. Excessive ROS contributed to the enhanced responses to ET-1 that may relate to reduced catalase and SOD2 expression. Blockade of canonical Wnt signaling in vivo were concomitant with restored SOD2 and catalase and normalized the arteriolar responses to ET1. Therefore, antioxidant strategies targeting canonical Wnt signaling may correct abnormal vascular function in diabetic nephropathy.

\section{Acknowledgements}

This study was supported by research grants to En Yin Lai from the National Nature Science Foundation of China (31471100 and 31671193), and the German Research Foundation (DFG PA 479/10-2).

\section{Disclosure Statement}

The authors have no conflicts of interest regarding the publication of this article.

\section{References}

\footnotetext{
1 Schnackenberg CG, Wilcox CS: The SOD mimetic tempol restores vasodilation in afferent arterioles of experimental diabetes. Kidney Int 2001;59:1859-1864.
} 


\section{Kidney \\ Blood Pressure Research}

Zhang et al.: ET-1 and Canonical Wnt Signaling in Afferent Arteriole

2 Khamaisi M, Raz I, Shilo V, Shina A, Rosenberger C, Dahan R, Abassi Z, Meidan R, Lecht S, Heyman SN: Diabetes and radiocontrast media increase endothelin converting enzyme- 1 in the kidney. Kidney Int 2008;74:91-100.

-3 Schneider JG, Tilly N, Hierl T, Sommer U, Hamann A, Dugi K, Leidig-Bruckner G, Kasperk C: Elevated plasma endothelin-1 levels in diabetes mellitus. Am J Hypertens 2002;15:967-972.

4 Bruno CM, Meli S, Marcinno M, Ierna D, Sciacca C, Neri S: Plasma endothelin-1 levels and albumin excretion rate in normotensive, microalbuminuric type 2 diabetic patients. J Biol Regul Homeost Agents 2002;16:114-117.

-5 Lai EY, Wellstein A, Welch WJ, Wilcox CS: Superoxide modulates myogenic contractions of mouse afferent arterioles. Hypertension 2011;58:650-656.

-6 Li L, Lai EY, Wellstein A, Welch WJ, Wilcox CS: Differential effects of superoxide and hydrogen peroxide on myogenic signaling, membrane potential, and contractions of mouse renal afferent arterioles. Am J Physiol Renal Physiol 2016;310:F1197-1205.

7 Li L, Lai EY, Luo Z, Solis G, Griendling KK, Taylor WR, Jose PA, Wellsten A, Welch WJ, Wilcox CS: Superoxide and hydrogen peroxide counterregulate myogenic contractions in renal afferent arterioles from a mouse model of chronic kidney disease. Kidney Int 2017; DOI: 10.1016/j.kint.2017.02.009.

8 Lai EY, Persson AE, Bodin B, Kallskog O, Andersson A, Pettersson U, Hansell P, Jansson L: Endothelin-1 and pancreatic islet vasculature: studies in vivo and on isolated, vascularly perfused pancreatic islets. Am J Physiol Endocrinol Metab 2007;292:E1616-1623.

-9 Granstam SO, Granstam E: Endothelin-induced changes in blood flow in STZ-diabetic and non-diabetic rats: relation to nitric oxide synthase and cyclooxygenase inhibition. J Physiol Sci 2011;61:497-505.

10 Sanchez A, Martinez P, Munoz M, Benedito S, Garcia-Sacristan A, Hernandez M, Prieto D: Endothelin-1 contributes to endothelial dysfunction and enhanced vasoconstriction through augmented superoxide production in penile arteries from insulin-resistant obese rats: role of ET(A) and ET(B) receptors. Br J Pharmacol 2014;171:5682-5695.

-11 Zou XR, Wang XQ, Hu YL, Zhou HL: Effects of Shen'an granules on Wnt signaling pathway in mouse models of diabetic nephropathy. Exp Ther Med 2016;12:3515-3520.

-12 Zhou T, He X, Cheng R, Zhang B, Zhang RR, Chen Y, Takahashi Y, Murray AR, Lee K, Gao G, Ma JX: Implication of dysregulation of the canonical wingless-type MMTV integration site (WNT) pathway in diabetic nephropathy. Diabetologia 2012;55:255-266.

13 Vikram A, Kim YR, Kumar S, Naqvi A, Hoffman TA, Kumar A, Miller FJ, Jr., Kim CS, Irani K: Canonical Wnt signaling induces vascular endothelial dysfunction via p66Shc-regulated reactive oxygen species. Arterioscler Thromb Vasc Biol 2014;34:2301-2309.

14 Yoon JC, Ng A, Kim BH, Bianco A, Xavier RJ, Elledge SJ: Wnt signaling regulates mitochondrial physiology and insulin sensitivity. Genes Dev 2010;24:1507-1518.

15 Lin CL, Wang JY, Ko JY, Surendran K, Huang YT, Kuo YH, Wang FS: Superoxide destabilization of beta-catenin augments apoptosis of high-glucose-stressed mesangial cells. Endocrinology 2008;149:2934-2942.

-16 Lee HJ, Wang NX, Shi DL, Zheng JJ: Sulindac inhibits canonical Wnt signaling by blocking the PDZ domain of the protein Dishevelled. Angew Chem Int Ed Engl 2009;48:6448-6452.

17 Patzak A, Lai EY, Mrowka R, Steege A, Persson PB, Persson AE: AT1 receptors mediate angiotensin IIinduced release of nitric oxide in afferent arterioles. Kidney Int 2004;66:1949-1958.

18 Lai EY, Patzak A, Persson AE, Carlstrom M: Angiotensin II enhances the afferent arteriolar response to adenosine through increases in cytosolic calcium. Acta Physiol (Oxf) 2009;196:435-445.

19 Huang Q, Wang Q Zhang S, Jiang S, Zhao L, Yu L, Hultstrom M, Patzak A, Li L, Wilcox CS, Lai EY: Increased hydrogen peroxide impairs angiotensin II contractions of afferent arterioles in mice after renal ischaemiareperfusion injury. Acta Physiol (Oxf) 2016;218:136-145.

20 Chaudhari A, Kirschenbaum MA: A rapid method for isolating rabbit renal microvessels. Am J Physiol 1988;254:F291-296.

21 Lai EY, Martinka P, Fahling M, Mrowka R, Steege A, Gericke A, Sendeski M, Persson PB, Persson AE, Patzak A: Adenosine restores angiotensin II-induced contractions by receptor-independent enhancement of calcium sensitivity in renal arterioles. Circ Res 2006;99:1117-1124.

22 Dar AA, Belkhiri A, El-Rifai W: The aurora kinase A regulates GSK-3beta in gastric cancer cells. Oncogene 2009;28:866-875. 


\section{Kidney \\ Blood Pressure Research}

23 Ogunbileje JO, Porter C, Herndon DN, Chao T, Abdelrahman DR, Papadimitriou A, Chondronikola M, Zimmers TA, Reidy PT, Rasmussen BB, Sidossis LS: Hypermetabolism and hypercatabolism of skeletal muscle accompany mitochondrial stress following severe burn trauma. Am J Physiol Endocrinol Metab 2016;311:E436-448.

-24 Sachidanandam K, Elgebaly MM, Harris AK, Hutchinson JR, Mezzetti EM, Portik-Dobos V, Ergul A: Effect of chronic and selective endothelin receptor antagonism on microvascular function in type 2 diabetes. Am J Physiol Heart Circ Physiol 2008;294:H2743-2749.

-25 Yousif MH: Role of protein kinases in mediating diabetes-induced augmented vasoconstriction to endothelin-1 in the renal arteries of STZ-diabetic rats. Cell Biochem Funct 2006;24:397-405.

-26 Singh DK, Winocour P, Farrington K: Oxidative stress in early diabetic nephropathy: fueling the fire. Nat Rev Endocrinol 2011;7:176-184.

27 Miller AF: Superoxide dismutases: ancient enzymes and new insights. FEBS Lett 2012;586:585-595.

28 Li L, Feng D, Luo Z, Welch WJ, Wilcox CS, Lai EY: Remodeling of Afferent Arterioles From Mice With Oxidative Stress Does Not Account for Increased Contractility but Does Limit Excessive Wall Stress. Hypertension 2015;66:550-556.

29 Zanetti M, Sato J, Katusic ZS, O’Brien T: Gene transfer of superoxide dismutase isoforms reverses endothelial dysfunction in diabetic rabbit aorta. Am J Physiol Heart Circ Physiol 2001;280:H2516-2523.

30 Nishikawa T, Edelstein D, Du XL, Yamagishi S, Matsumura T, Kaneda Y, Yorek MA, Beebe D, Oates PJ, Hammes HP, Giardino I, Brownlee M: Normalizing mitochondrial superoxide production blocks three pathways of hyperglycaemic damage. Nature 2000;404:787-790.

-31 Sivitz WI, Yorek MA: Mitochondrial dysfunction in diabetes: from molecular mechanisms to functional significance and therapeutic opportunities. Antioxid Redox Signal 2010;12:537-577.

-32 Kassab A, Piwowar A: Cell oxidant stress delivery and cell dysfunction onset in type 2 diabetes. Biochimie 2012;94:1837-1848.

-33 Ceriello A, dello Russo P, Amstad P, Cerutti P: High glucose induces antioxidant enzymes in human endothelial cells in culture. Evidence linking hyperglycemia and oxidative stress. Diabetes 1996;45:471477.

-34 Headley CA, DiSilvestro D, Bryant KE, Hemann C, Chen CA, Das A, Ziouzenkova O, Durand G, Villamena FA: Nitrones reverse hyperglycemia-induced endothelial dysfunction in bovine aortic endothelial cells. Biochem Pharmacol 2016;104:108-117.

-35 Qian LB, Wang HP, Chen Y, Chen FX, Ma YY, Bruce IC, Xia Q: Luteolin reduces high glucose-mediated impairment of endothelium-dependent relaxation in rat aorta by reducing oxidative stress. Pharmacol Res 2010;61:281-287.

-36 Bagi Z, Koller A, Kaley G: PPARgamma activation, by reducing oxidative stress, increases NO bioavailability in coronary arterioles of mice with Type 2 diabetes. Am J Physiol Heart Circ Physiol 2004;286:H742-748.

37 Weidig P, McMaster D, Bayraktutan U: High glucose mediates pro-oxidant and antioxidant enzyme activities in coronary endothelial cells. Diabetes Obes Metab 2004;6:432-441.

-38 Fellner SK, Arendshorst W: Endothelin-A and -B receptors, superoxide, and Ca2+ signaling in afferent arterioles. Am J Physiol Renal Physiol 2007;292:F175-184.

-39 Ardanaz N, Pagano PJ: Hydrogen peroxide as a paracrine vascular mediator: regulation and signaling leading to dysfunction. Exp Biol Med (Maywood) 2006;231:237-251.

40 Chettimada S, Ata H, Rawat DK, Gulati S, Kahn AG, Edwards JG, Gupte SA: Contractile protein expression is upregulated by reactive oxygen species in aorta of Goto-Kakizaki rat. Am J Physiol Heart Circ Physiol 2014;306:H214-224.

41 Zhao L, Wang Y, Ma X, Wang Y, Deng X: Oxidative stress impairs IKCa- and SKCa-mediated vasodilatation in mesenteric arteries from diabetic rats. Nan Fang Yi Ke Da Xue Xue Bao 2013;33:939-944.

42 Barker N: The canonical Wnt/beta-catenin signalling pathway. Methods Mol Biol 2008;468:5-15.

43 Singh R, De Aguiar RB, Naik S, Mani S, Ostadsharif K, Wencker D, Sotoudeh M, Malekzadeh R, Sherwin RS, Mani A: LRP6 enhances glucose metabolism by promoting TCF7L2-dependent insulin receptor expression and IGF receptor stabilization in humans. Cell Metab 2013;17:197-209.

-44 Zhou T, Zhou KK, Lee K, Gao G, Lyons TJ, Kowluru R, Ma JX: The role of lipid peroxidation products and oxidative stress in activation of the canonical wingless-type MMTV integration site (WNT) pathway in a rat model of diabetic retinopathy. Diabetologia 2011;54:459-468. 


\section{Kidney Research}

45 Tai WP, Hu PJ, Wu J, Lin XC: The inhibition of Wnt/beta-catenin signaling pathway in human colon cancer cells by sulindac. Tumori 2014;100:97-101.

-46 Kajla S, Mondol AS, Nagasawa A, Zhang Y, Kato M, Matsuno K, Yabe-Nishimura C, Kamata T: A crucial role for Nox 1 in redox-dependent regulation of Wnt-beta-catenin signaling. FASEB J 2012;26:2049-2059.

47 Shin SY, Kim CG, Jho EH, Rho MS, Kim YS, Kim YH, Lee YH: Hydrogen peroxide negatively modulates Wnt signaling through downregulation of beta-catenin. Cancer Lett 2004;212:225-231.

48 Ma S, Yao S, Tian H, Jiao P, Yang N, Zhu P, Qin S: Pigment epithelium-derived factor alleviates endothelial injury by inhibiting Wnt/beta-catenin pathway. Lipids Health Dis 2017;16:31.

49 Zhou T, Hu Y, Chen Y, Zhou KK, Zhang B, Gao G, Ma JX: The pathogenic role of the canonical Wnt pathway in age-related macular degeneration. Invest Ophthalmol Vis Sci 2010;51:4371-4379.

50 Zhang DY, Pan Y, Zhang C, Yan BX, Yu SS, Wu DL, Shi MM, Shi K, Cai XX, Zhou SS, Wang JB, Pan JP, Zhang LH: Wnt/beta-catenin signaling induces the aging of mesenchymal stem cells through promoting the ROS production. Mol Cell Biochem 2013;374:13-20. 